\begin{tabular}{|l|l|l||}
\hline \multicolumn{2}{|c|}{ PublisherInfo } \\
\hline \hline PublisherName & $:$ & BioMed Central \\
\hline \hline PublisherLocation & $:$ & London \\
\hline \hline PublisherImprintName & $:$ & BioMed Central \\
\hline \hline
\end{tabular}

\title{
Plant-to-plant horizontal gene transfer
}

\begin{tabular}{|l|l|l||}
\hline \multicolumn{2}{|c|}{ ArticleInfo } \\
\hline \hline ArticleID & $:$ & 4809 \\
\hline \hline ArticleDOI & $:$ & $10.1186 /$ gb-spotlight-20030710-01 \\
\hline \hline ArticleCitationID & $:$ & spotlight-20030710-01 \\
\hline \hline ArticleSequenceNumber & $:$ & 161 \\
\hline \hline ArticleCategory & $:$ & Research news \\
\hline ArticleFirstPage & $:$ & 1 \\
\hline \hline ArticleLastPage & $:$ & 2 \\
\hline \hline & & RegistrationDate : 2003-7-10 \\
\hline ArticleHistory & $:$ & OnlineDate \\
\hline \hline ArticleCopyright & $:$ & BioMed Central Ltd2003-7-10 \\
\hline \hline ArticleGrants & $:$ & \\
\hline \hline ArticleContext & $:$ & 130594411 \\
\hline \hline
\end{tabular}




\section{Bishop}

Email: cleo.bishop@imperial.ac.uk

Horizontal gene transfer (HGT) is the transfer of genetic material between distinct species, a process that plays a major role in the evolution of a genome. There is an increasing body of evidence for the transfer of genes between eukaryotes, but the complexities of transcription and translation regulation in eukaryotes have always been thought to be a barrier to HGT. In the July 10 Nature, Ulfar Bergthorsson and colleagues at Indiana University show that standard mitochondrial genes are subject to frequent HGT between distantly related angiosperms, implying the presence of a mechanism for transfer of DNA between unrelated plants (Nature, 424:197-201, July 10, 2003).

Bergthorsson et al. surveyed the mitochondrial gene content of a number of angiosperms and found distribution anomalies. Phylogenetic analysis of two mitochondrial ribosomal protein genes - rps 2 and rps 11 - resulted in the identification of four cases of plant-to-plant HGT, suggesting that the frequency of HGT is significant. The authors also suggest that previous placements of the atpl gene should be reclassed as an HGT event. Expression analysis of Sanguinaria indicated that the rps 11 RNA is probably functional and that the atp1 gene of Amborella is transcribed and edited. Using molecularclock - based divergence times, the age of each transfer was also estimated.

"These results establish for the first time that conventional genes are subject to evolutionarily frequent HGT during plant evolution and provide the first unambiguous evidence that plants can donate DNA horizontally to other plants. This is also the best evidence that eukaryotic genomes regularly acquire genes by means of horizontal events that are relatively recent, datable and definable as to donor and recipient," conclude the authors.

\section{References}

1. Horizontal gene transfer and the origin of species: lessons from bacteria

2. Nature, [http://www.nature.com/nature/]

3. Indiana University, [http://www.indiana.edu] 